\title{
Feeding value of raw and boiled pigeon pea seed meal on the growth performance of local pullet chicks
}

Amaefule, K. $\mathrm{U}^{+}$. and Okereke, C. O*.

${ }^{+}$Department of Animal Nutrition and Forage Science,

Michael Okpara University of Agriculture, Umudike.

"National Root Crops Research Institute Umudike, Umuahia, Abia State, Nigeria.

*Corresponding author:ogbokereke2009@yahoo.com

\section{Abstract}

A total of 324 local pullet chicks (1-8 weeks) were used for the research project to evaluate the feeding value of raw and boiled pigeon pea seed meal (PSM) on their growth performance. Nine iso-caloric and isonitrogenous diets were formulated, with raw and boiled pigeon pea seed meal at inclusion levels of $0 \%, 15 \%, 20 \%, 25 \%$ and 30\%, respectively. There were 36 chicks per treatment replicated into 3 at 12 chicks per replicate. There were significant interactions between form and PSM levels on the final live weight, daily feed intake and daily protein intake. Final live weight of pullets fed both raw and boiled PSM followed the same trend, pullets fed control (0\%) and 15\% raw PSM 128.10 and $132.33 \mathrm{~g}$ respectively performed better than the rest of the treatment levels but statistically similar at all levels. Daily feed intake and daily protein intake showed significant interaction among the treatments. Pullets fed control $(8.95 \mathrm{~g})$ and raw diets $(8.79 \mathrm{~g})$ consumed more feed than pullets fed boiled PSM II (105.05g), III (117.77g) IV (91.27g) and V (112.80g) diets. Daily weight gain, feed conversion ratio and protein efficiency ratio had no significant $(P>0.05)$ interaction between form and treatment groups for the pullets. 30\% PSM raw or boiled can be fed to local pullet chicks without any deleterious effect on the growth performance.

Keywords: Raw PSM, Boiled PSM, Feeding value, Growing local pullet.

\section{Introduction}

Nigeria is currently faced with short supply and high cost of conventional feed ingredients for poultry rations. Poultry feeds are expensive due to high cost of soybean meal, maize and fish meal (Amaefule et al., 2006b). Over the years, there has been much effort directed towards the exploitation and the use of nonconventional ingredients in feed production. The availability of these feedstuffs also depends much on yields per season, government economic policies especially as it affects importation of raw material and agricultural products; and industrial processing activities (Oluyemi and Roberts, 2000). Pigeon pea seeds have very low human food preference and no industrial use as at now (Amaefule and
Nwagbara, 2004). Pigeon pea seeds are one of the non-conventional feedstuffs that is being developed as an alternative to maize, soybean meal and/or groundnut cake in broiler (Tangtaweewipat and Elliot, 1988, 1989a; Amaefule and Obioha, 1998; Amaefule and Onwudike, 2000; Amaefule and Obioha, 2001; Onu and Okongwu, 2006; Amaefule et al., 2011), in Pullet chicks (Amaefule and Nwagbara, 2004; Amaefule and Obioha, 2005) and in layer (Udedibie and Igwe, 1989; Agwunobi, 2000; Amaefule et al., 2006c Amaefule et al., 2007a; Amaefule et al., 2007b) diets. It is available in commercial quantities throughout the year and can be sourced in any part of Nigeria and neighbouring countries. This study aims to assess the growth performance, the replacement value 


\section{Feeding value of raw and boiled pigeon pea seed meal}

of raw or boiled pigeon pea seed meal for soybean meal and maize in diets of local chickens.

\section{Materials and methods}

Raw pigeon pea seeds were cleaned of dust, sand and other undesirable materials, milled with seed coat at the National Root Crops Research Institute feed mill (Skiold millmix ${ }^{R}$ ). The particles were milled to pass through a $2 \mathrm{~mm}$ sieve. The resulting raw PSM were used for the feeding trial. The pigeon peas were boiled as described by
Amaefule et al (2006b). Raw pigeon pea seeds were cleaned of dust, sand and other undesirable materials, put in boiling water temperature $100^{\circ} \mathrm{C}$, boiled for 30 minutes with a big cooking pot heated under fire wood and then water decanted using an aluminum sieve, and then sun dried on a clean nylon mat.

\section{Experimental diets}

Nine iso-caloric and isonitrogenous diets were formulated, with raw and boiled pigeon pea seed meal at inclusion levels of I (0\%), II (15\%), III (20\%), IV (25\%) and (V) $30 \%$, respectively Table 1 .

Table 1: Percentage composition of graded levels of raw or boiled pigeon pea seed meals diets fed to local pullets $\left(1^{\text {st }}-8\right.$ weeks $)$.

\begin{tabular}{|c|c|c|c|c|c|}
\hline Feedstuffs & $\mathrm{I}(0 \%)$ & II $(15 \%)$ & III $(20 \%)$ & IV $(25 \%)$ & $\mathrm{V}(30 \%)$ \\
\hline Pigeon pea seed meal & 0.00 & 15.00 & 20.00 & 25.00 & 30.00 \\
\hline White maize & 48.16 & 38.45 & 35.22 & 31.98 & 28.75 \\
\hline Soybean meal & 20.41 & 15.12 & 13.35 & 11.39 & 9.82 \\
\hline Wheat offal & 25.93 & 25.93 & 25.93 & 25.93 & 25.93 \\
\hline Local fish meal & 2.00 & 2.00 & 2.00 & 2.00 & 2.00 \\
\hline Bone meal & 3.00 & 3.00 & 3.00 & 3.00 & 3.00 \\
\hline Vitamin premix* & 0.25 & 0.25 & 0.25 & 0.25 & 0.25 \\
\hline Salt & 0.25 & 0.25 & 0.25 & 0.25 & 0.25 \\
\hline Total $\%$ & 100 & 100 & 100 & 100 & 100 \\
\hline \multicolumn{6}{|l|}{ Calculated values } \\
\hline $\mathrm{CP}(\%)$ & 18 & 18 & 18 & 18 & 18 \\
\hline CF $(\%)$ & 4.21 & 3.68 & 3.51 & 3.33 & 3.15 \\
\hline $\mathrm{Ca}(\%)$ & 1.27 & 1.48 & 1.55 & 1.62 & 1.69 \\
\hline $\mathrm{P}(\%)$ & 0.72 & 1.03 & 1.13 & 1.23 & 1.33 \\
\hline $\mathrm{ME} \mathrm{MJ/kg}$ & 11.74 & 11.61 & 11.57 & 11.52 & 11.48 \\
\hline Lysine $\%$ & 1.04 & 1.09 & 0.89 & 1.09 & 0.89 \\
\hline Methionine \% & 0.37 & 0.31 & 0.51 & 0.51 & 0.31 \\
\hline ME: CP ratio & 119.51 & 121.03 & 121.03 & 121.03 & 121.03 \\
\hline
\end{tabular}

\section{Chick stage (1-56 days)}

A total of 324 local pullet chicks (1- 8 weeks) were used for the research project. There were 36 chicks per treatment replicated into 3 at 12 chicks per replicate. The chicks were brooded and reared on a deep litter system in an open-sided poultry house whose sides and demarcations between pens were covered with black tarpaulin hanging from the outside, each of the deep litter pen measured 62 x $68 \mathrm{~cm}$. Heat was supplied with kerosene stoves under metal hovers. Standard management practices were followed during the brooding stage. Feed and water were provided to the chicks ad libitum. The chicks were vaccinated against Newcastle, Gumboro diseases, fowl pox, typhoid and 


\section{Amaefule and Okereke}

cholera, antibiotics, coccidiostat and antistress were also given to the chicks. The litter material was wood shavings.

\section{Data analysis}

The experimental design was factorial arrangement in a completely randomized design (CRD). All data obtained were subjected to analysis of variance procedure according to the method of SAS.

\section{Results and discussion}

Effect of levels of inclusion of boiled PSM fed to local pullet chicks

There were no significant differences
$(\mathrm{P}<0.05)$ in daily weight gain, feed conversion ratio and protein efficiency ratio (Table 2). Final live weight of pullet chicks fed $0 \%$ boiled PSM were significantly higher $(\mathrm{P}<0.05)$ than those pullet chicks fed $25 \%$ but similar to those of pullet chicks, fed diets 15, 20 and 30\%. Daily feed intake and protein intake were significantly different $(\mathrm{P}<0.05)$ but followed similar pattern. Daily feed intake and daily protein intake of pullet chicks fed control diet $0 \%$ were significantly $(\mathrm{P}<0.05)$ higher than those of pullet chicks fed the rest of treatment diets, while pullet chicks fed 15, 20, 25 and $30 \%$ PSM diets were similar.

Tables 2: Growth performance of local pullet chicks ( 1 - 8 weeks) fed graded levels of boiled pigeon pea seed meal (PSM).

\begin{tabular}{lllllll}
\hline Parameters & $0 \%$ & $15 \%$ & $20 \%$ & $25 \%$ & $30 \%$ & SEM \\
\hline Initial live weight $(\mathrm{g})$ & 25.21 & 25.15 & 25.27 & 25.22 & 25.26 & 1.01 \\
Final live weight $(\mathrm{g})$ & $128.10^{\mathrm{a}}$ & $105.02^{\mathrm{ab}}$ & $117.77^{\mathrm{ab}}$ & $91.27^{\mathrm{b}}$ & $112.80^{\mathrm{ab}}$ & 10.55 \\
Daily feed intake $(\mathrm{g})$ & $8.95^{\mathrm{a}}$ & $7.73^{\mathrm{b}}$ & $7.52^{\mathrm{b}}$ & $7.47^{\mathrm{b}}$ & $7.66^{\mathrm{b}}$ & 0.14 \\
Daily weight gain $(\mathrm{g})$ & 4.18 & 2.82 & 3.71 & 2.48 & 3.69 & 0.54 \\
Feed conversion ratio & 2.38 & 2.86 & 2.03 & 3.02 & 2.21 & 0.36 \\
Daily protein intake $(\mathrm{g})$ & $1.61^{\mathrm{a}}$ & $1.39^{\mathrm{b}}$ & $1.36^{\mathrm{b}}$ & $1.35^{\mathrm{b}}$ & $1.38^{\mathrm{b}}$ & 0.03 \\
Protein efficiency ratio & 2.59 & 2.03 & 2.74 & 1.85 & 2.67 & 0.37 \\
\hline
\end{tabular}

a, b, Means in the same row followed by different superscript are significantly $(\mathrm{P}<0.05)$ different.

SEM: Standard error of mean.

Effect of levels of inclusion of raw PSM fed to local pullet chicks

Dietary treatments had no significant $(\mathrm{P}>0.05)$ effect on final live weight, daily weight gain, feed conversion ratio, and protein efficiency ratio (Table 3). Daily feed intake and daily protein intake showed significant differences $(\mathrm{P}<0.05)$ their distribution followed similar pattern.
Pullets fed 25\% raw PSM diets had significantly reduced $(\mathrm{P}<0.05)$ feed intake than those fed $20 \%$ raw diets. There was no significant difference $(\mathrm{P}>0.05)$ in feed intake among birds fed 0, 15, 20 and 30\% PSM diets and also among birds fed 0, 15, 25 and 30\% raw PSM diets. Protein intake of local pullets (1-8weeks) fed raw PSM diets followed exactly the same pattern as feed intake.

Tables 3: Growth performance of local pullets ( 1 - 8 weeks) fed graded levels of raw pigeon pea seed meal (PSM)

\begin{tabular}{lllllll}
\hline Parameters & $0 \%$ & $15 \%$ & $20 \%$ & $25 \%$ & $30 \%$ & SEM \\
\hline Initial live weight $(\mathrm{g})$ & 25.21 & 25.23 & 25.24 & 25.21 & 25.34 & 1.01 \\
Final live weight $(\mathrm{g})$ & 128.10 & 132.33 & 102.70 & 130.28 & 107.45 & 10.95 \\
Daily feed intake $(\mathrm{g})$ & $8.95^{\mathrm{ab}}$ & $8.79^{\mathrm{ab}}$ & $9.38^{\mathrm{a}}$ & $8.69^{\mathrm{b}}$ & $8.95^{\mathrm{ab}}$ & 0.18 \\
Daily weight gain $(\mathrm{g})$ & 4.18 & 3.69 & 3.04 & 4.19 & 3.16 & 0.50 \\
Feed conversion ratio & 2.38 & 2.38 & 3.43 & 2.09 & 2.85 & 0.46 \\
Daily protein intake $(\mathrm{g})$ & $1.61^{\mathrm{ab}}$ & $1.58^{\mathrm{ab}}$ & $1.69^{\mathrm{a}}$ & $1.57^{\mathrm{b}}$ & $1.61^{\mathrm{ab}}$ & 0.03 \\
Protein efficiency ratio & 2.59 & 2.34 & 1.80 & 2.68 & 1.96 & 0.32 \\
\hline
\end{tabular}

a, b, Means in the same row followed by different superscript are significantly $(\mathrm{P}<0.05)$ different. 


\section{Feeding value of raw and boiled pigeon pea seed meal}

Interaction between form and levels of PSMfed to local pullet chicks

Table: 4 show the effect of interaction between form of pigeon pea seed meal and inclusion levels in the diets on local chick pullet (1-8 weeks) performance. There were significant interactions between form and PSM levels on the pullets in final live weight, daily feed intake and daily protein intake. Final live weight of pullets fed both raw and boiled PSM followed the same trend, pullets fed control ( $0 \%)$ and $15 \%$ raw PSM slightly performed better than the rest of the treatment levels but statistically similar at all levels. Daily feed intake and daily protein intake showed significant interaction among the treatments. Pullets on control and raw diets had more intake than pullets on boiled PSM diets. Daily weight gain, feed conversion ratio and protein efficiency ratio had no significant $(\mathrm{P}>0.05)$ interaction between form and treatment groups for the pullets.

Table 4: Effect of interaction between form of pigeon pea seed meal and inclusion levels in the diets on local chick pullet (1-8 weeks) performance

\begin{tabular}{|c|c|c|c|c|c|c|c|}
\hline Parameter & Form & $0 \%$ & $15 \%$ & $20 \%$ & $25 \%$ & $30 \%$ & SEM \\
\hline \multirow[t]{2}{*}{ Initial live weight (g) } & Raw & 25.21 & 25.23 & 25.24 & 25.21 & 25.34 & 1.01 \\
\hline & Boiled & 25.21 & 25.15 & 25.27 & 25.22 & 25.26 & \\
\hline \multirow[t]{2}{*}{ Final live weight (g) } & Raw & $128.10^{\mathrm{a}}$ & $132.33^{\mathrm{a}}$ & $102.70^{\mathrm{ab}}$ & $102.70^{\mathrm{ab}}$ & $107.45^{\mathrm{ab}}$ & 10.75 \\
\hline & Boiled & $128.10^{\mathrm{a}}$ & $105.02^{\mathrm{ab}}$ & $117.77^{\mathrm{ab}}$ & $91.26^{\mathrm{ab}}$ & $112.80^{\mathrm{ab}}$ & \\
\hline \multirow[t]{2}{*}{ Daily feed intake (g) } & Raw & $8.95^{\mathrm{ab}}$ & $8.79^{\mathrm{b}}$ & $9.38^{\mathrm{a}}$ & $8.69^{\mathrm{b}}$ & $8.95^{\mathrm{ab}}$ & 0.16 \\
\hline & Boiled & $8.95^{\mathrm{ab}}$ & $7.73^{c}$ & $7.52^{c}$ & $7.47^{\mathrm{c}}$ & $7.66^{\mathrm{c}}$ & \\
\hline \multirow[t]{2}{*}{ Daily weight gain (g) } & Raw & 4.18 & 3.69 & 3.04 & 4.19 & 3.16 & 0.52 \\
\hline & Boiled & 4.18 & 2.82 & 3.71 & 2.48 & 3.69 & \\
\hline \multirow[t]{2}{*}{ Feed conversion ratio } & Raw & 2.38 & 2.38 & 3.43 & 2.09 & 2.85 & 0.41 \\
\hline & Boiled & 2.38 & 2.86 & 2.03 & 3.02 & 2.21 & \\
\hline \multirow[t]{2}{*}{ Daily protein intake } & Raw & $1.61^{\mathrm{ab}}$ & $1.58^{\mathrm{b}}$ & $1.69^{\mathrm{a}}$ & $1.57^{\mathrm{b}}$ & $1.61^{\mathrm{ab}}$ & 0.03 \\
\hline & Boiled & $1.61^{\mathrm{ab}}$ & $1.39^{c}$ & $1.36^{\mathrm{c}}$ & $1.35^{\mathrm{c}}$ & $1.38^{\mathrm{c}}$ & \\
\hline \multirow{2}{*}{$\begin{array}{l}\text { Protein efficiency } \\
\text { ratio }\end{array}$} & Raw & 2.59 & 2.34 & 1.80 & 2.68 & 1.96 & 0.34 \\
\hline & Boiled & 2.59 & 2.03 & 2.74 & 1.85 & 2.67 & \\
\hline
\end{tabular}

Effect of form of pigeon pea seed meal

Pigeon pea seed meal in the diet of local pullets (1-8 weeks) on performance showed that, apart from daily feed and daily protein intake the rest of the parameters evaluated showed no significant differences. These distributions followed similar pattern with local pullet chick fed raw PSM, it had higher intake than those fed boiled as represented on Table 5 .

Table 5: Effect of form of pigeon pea seed meal in the diets on local chick pullet ( $1-8$ weeks) performance

\begin{tabular}{llll}
\hline Parameter & Raw & Boiled & SEM \\
\hline Initial live weight $(\mathrm{g})$ & 25.25 & 25.22 & 0.45 \\
Final live weight $(\mathrm{g})$ & 120.17 & 110.99 & 4.81 \\
Daily feed intake $(\mathrm{g})$ & $8.95^{\mathrm{a}}$ & $7.87^{\mathrm{b}}$ & 0.07 \\
Daily weight gain $(\mathrm{g})$ & 3.65 & 3.38 & 0.23 \\
Feed conversion ratio & 2.63 & 2.50 & 0.19 \\
Daily protein intake & $1.61^{\mathrm{a}}$ & $1.42^{\mathrm{b}}$ & 0.01 \\
Protein efficiency ratio & 2.28 & 2.38 & 0.15 \\
\hline
\end{tabular}

${ }^{\mathrm{a}, \mathrm{b}}$,Means in the same row followed by different superscript are significantly $(\mathrm{P}<0.05)$ different. SEM: Standard error of mean. 


\section{Amaefule and Okereke}

Effect of level of inclusion of pigeon pea seed meal

Furthermore, local pullet chicks fed various levels of PSM diets showed no significant differences in final live weight, daily weight gain, feed conversion ratio and protein efficiency ratio. Daily feed intake and daily protein intake followed almost the same pattern with local pullet chicks fed $0 \%$ PMS had significantly higher intakes than those fed the rest of the treatment levels.

Table 6: Effect of level of inclusion of pigeon pea seed meal in the diets on local chick pullet (1 -8 weeks) performance

\begin{tabular}{lllllll}
\hline Parameter & $0 \%$ & $15 \%$ & $20 \%$ & $25 \%$ & $30 \%$ & SEM \\
\hline Initial live weight $(\mathrm{g})$ & 25.21 & 25.19 & 25.25 & 25.22 & 25.30 & 0.72 \\
Final live weight $(\mathrm{g})$ & 128.10 & 118.68 & 110.23 & 110.77 & 110.13 & 7.60 \\
Daily feed intake $(\mathrm{g})$ & $8.95^{\mathrm{a}}$ & $8.26^{\mathrm{bc}}$ & $8.45^{\mathrm{b}}$ & $8.08^{\mathrm{c}}$ & $8.30^{\mathrm{bc}}$ & 0.12 \\
Daily weight gain $(\mathrm{g})$ & 4.18 & 3.26 & 3.38 & 3.34 & 3.43 & 0.37 \\
Feed conversion ratio & 2.38 & 2.62 & 2.73 & 2.55 & 2.53 & 0.29 \\
Daily protein intake & $1.61^{\mathrm{a}}$ & $1.49^{\mathrm{b}}$ & $1.52^{\mathrm{b}}$ & $1.46^{\mathrm{b}}$ & $1.50^{\mathrm{b}}$ & 0.02 \\
Protein efficiency ratio & 2.59 & 2.19 & 2.27 & 2.27 & 2.32 & 0.24 \\
\hline
\end{tabular}

a, b, c, Means in the same row followed by different superscript are significantly $(\mathrm{P}<0.05)$ different. SEM: Standard error of mean.

\section{Discussion}

\section{Effect of levels of inclusion of boiled PSM fed to local pullet chicks on performance}

The final live weight showed significant differences, pullets fed diet I $(0 \%)$ been significantly higher than pullets fed treatment IV $(25 \%)$ but statistically similar to pullets on diets II (15\%), III (20\%) and V (30\%). Lesson and Summers (1989) pointed out that pullets' growth was more sensitive to dietary energy concentrations. Lesson (1990) furthermore observed that high early pullet's growth rate (0-8 weeks) is likely to be more sensitive to amino acid intake than to energy intake. Daily feed intake and daily protein intake of local pullets fed $0 \%$ PSM diet was significantly $(\mathrm{P}<0.05)$ higher than those of pullets fed other treatment diets, while pullets fed boiled PSM diets were similar. Although local pullets fed $1(0 \%)$ PSM diets had higher energy in their diet Table 1, they consumed significantly $(\mathrm{P}<0.05)$ more feed and had significantly $(\mathrm{P}<0.05)$ higher live weight than those fed 15, 20, 25 and $30 \%$ diets. These did not translate into better efficiency. No significant $(\mathrm{P}>0.05)$ differences were recorded in the rest of the parameters evaluated, this showed that boiled PSM successfully replaced soybean and maize in the experimental diet without adverse effect on performance of the birds. Effect of levels of inclusion of raw PSM fed to local pullet chicks on performance Observation on the daily feed intake and daily protein intakes of local pullets revealed that intake increased with increase in raw PSM in the diet. However, the increase $(\mathrm{P}<0.05)$ in the feed intake as the level of dietary energy decreased was noticed among the dietary treatments. This supported the report that feed consumption in birds is governed by the energy level of diet and that birds eat primarily to satisfy their energy needs (Bamgbose and Tewe, 1994; Angulo et al., 1993; Idowu et al., 2003 and Abeke et al., 2008). In addition, as feed intake increased significantly $(\mathrm{P}<0.05)$ from $0 \%$ to $30 \%$ inclusion it resulted to increased passage rate of the more fibrous digesta in the small intestine. This observation agreed with the report of Sundu (2009) that hard and fibrous feed stuffs may increase the contraction of the gizzard and may speed up the peristaltic movement of the digesta which could in turn result in 


\section{Feeding value of raw and boiled pigeon pea seed meal}

increased feed intake.

Interaction between form and levels of PSM fed to local pullet chicks on performance

The feed intake of pullets fed diets containing raw PSM was significantly $(\mathrm{P}<0.05)$ higher than those containing boiled PSM, this however did not result in better weight gain for pullets fed raw than boiled PSM. The birds apparently increased their intake due to reason above. This suggests that nutrients in the raw PSM were not as available as they were in the processed diets (Amaefule and Obioha, 2001). Protein intake followed similar trend as the feed intake, from the result one can conclude that feed intake in this trial was synonymous with the protein intake. The high intake of raw PSM as confirmed by (Amaefule and Onwudike, 2000; Amaefule and Obioha, 2001; Onu and Okongwu, 2006) on broilers and exotic pullets was the same with local pullets.

\section{Effect of form of pigeon pea seed meal on performance}

The increase in the consumption of raw PSM diets could be an attempt of the pullets to meet nutrient requirements from a diet that contained some antinutritional substances as has been observed with broilers (Amaefule and Onwudike, 2000; Amaefule and Obioha, 2003; Onu and Okongwu, 2006).

The feed intake trend, followed pattern of growth rate, this may have been in response to nutrient requirements for growth and development. The rest of the parameters evaluated were not affected by form (raw or boiled) PSM.

\section{Effect of level of inclusion of pigeon pea seed meal on performance}

The effect of inclusion levels of PSM in the diet of local pullet (1-8 week) on performance showed that there were no significant differences $(\mathrm{P}>0.05)$ in final live weight, daily weight gain, feed conversion ratio and protein efficiency ratio among the treatments. The implication of these result was that those parameters measured were not significantly $(\mathrm{P}>0.05)$ influenced by the dietary levels of PSM on local pullets. Better intakes of control diet over PSM diets could be due to presence of saponins. Saponins confer bitter taste to seed meal and depress growth and performance of animals through the irritation of the lining of the months and entire gut (Olomu, 1995). Boiling could not reduce the effect, since saponins is one of the secondary plant metabolites that is heat-stable and this group include condensed tannins, alkaloids and pyrimidine glycosides (D'Mello, 1995a).

\section{Conclusion}

$30 \%$ PSM raw or boiled can be fed to local pullet chicks without any deleterious effect on the growth performance.

\section{References}

Abeke, F. O., Ogundipe, S. O., Sekoni, A. A., Adeyinka, I. A., Oni, O. O., Abeke, A., Dafwang, I. I., 2008. Effect of duration of cooking Lablab purpurers beans on its utilization by broiler finishers (48weeks). Asian J. Anim. Vet. Adv., 3 (2) :85-91.

Agwunobi, L. N. 2000. Effect of feeding heat treated soybean (Glycine max) and pigeon pea (Cajanus cajan) as major sources of protein on layer performance. Global Journal of Pure and Applied Science. 6: 1-3.

Amaefule, K. U., Ojewole, G. S. and Ironkwe, M. C. 2006b. Pigeon Pea (Cajanus cajan) Seed Meal as Protein Source for Pullets: 2. Response of Pullets to Higher Inclusion Level and Prolonged Feeding of Raw or Processed Pigeon Pea Seed Meal Diets. 
International Journal of Poultry Science 4 (3): 289-295.

Amaefule, K. U., Ironkwe, M. C. and Obioha, F. C. 2006c. Pigeon Pea [Cajanus cajan (L.) Millsp.] Seed Meal in Layer Diets: 1. Performance of Point of Lay Pullets Fed Raw or Processed Pigeon Pea Seed Meal Diets. International Journal of Poultry Science 5 (7): 639-645.

Amaefule, K. U., Oke, U. K. and Obioha, F. C. 2007a. Pigeon Pea [Cajanus cajan (L.) Millsp.] Seed Meal in Layer Diets: 2. Laying Performance and Egg Quality Characteristics of Pullets Fed Raw or Processed Pigeon Pea Seed Meal Diets During Grower and Layer Stages of Life. International Journal of Poultry Science 6 (6): 445-451,

Amaefule, K. U., Oguike, M. A., Ironkwe, M. C. and Obioha, F. C. 2007b. Pigeon Pea [Cajanus cajan (L.) Millsp.] Seed Meal in Layer Diets: 3. Effect of Higher Inclusion Level and Prolonged Feeding of Raw or Processed Pigeon Pea Seed Meal Diets from Pullet Chick Stage on the Laying Performance of Pullets. International Journal of Poultry Science 6 (6): 452-458.

Amaefule, K. U. and Nwagbara, N. N. 2004. The effect of processing on nutrient utilization of Pigeon pea (Cajanus cajan) seed meal and pigeon pea seed meal based by pullets. Inter. Poult. Sci., 3: 543546.

Amaefule, K. U. and Obioha, F. C. 1998. The substitution of pigeon pea seed (Cajanus cajan) for groundnut cake and maize in broiler finisher ration. Nigerian Journal of Animal Production. 25:9-12.
Amaefule, K. U. and Obioha, F. C. 2001. Performance and Nutrient utilization of broiler starters fed diets containing raw, boiled or dehulled pigeon pea seeds (Cajanus cajan). Nig. J. Anim. Prod., 28: 31-39.

Amaefule, K. U. and Obioha, F. C. 2005. Performance of pullet chicks fed raw or processed pigeon pea (Cajanus cajan) seed meal diet. Livestock Research for Rural Development (LRRD), Vol. 17, Art. \# 13s. Retrieved from http:// w w w.ci pav.org.co/Irrd 17/03/amaeI7033.htm.

Amaefule, K. U. and Onwudike, O. C. 2000. Comparative evaluation of the processing methods of pigeon pea seeds (Cajanus cajan) as protein source for broilers. Journal of Sustainable Agriculture and the Environment. 1:134-136.

Amaefule, K. U., Ukpanah, U. A. and Ibok, A. E. 2011. Performance of starter broilers fed raw pigeon pea [Cajanus cajan (L.) Millsp.] seed meal diets supplemented with lysine and/or methionine. International Journal of Poultry Science 10 (3): 205-211.

Angulo, E., Miquel, A. and Steve, E. 1993. Effect of density and pelleting on production parameters of Japenese quail. Poult. Sci., 72:607-610.

Bamgbose, A. M. and Tewe, O. O. 1994. Performance and egg characteristics of layers fed extruded corn- soybean meal based diets at three energy levels. Journal Animal Production research. 14 (172):59-67.

D'Mello, J. P. F. 1995a. Antinutritional substances in legume seeds in D'Mello D P F and Devendra C (editors). Tropical Legumes in 


\section{Feeding value of raw and boiled pigeon pea seed meal}

Animal Nutrition, CAB International, Wallingford, UK. Pp135-172.

Idowu, O. M. O., Eruvbetine, D., Oduguwa, O. O. and Abiola, S. S. 2003. Response of finishingbroiler chickens fed three energy) protein combinations at fixed E.P. ratio. Nigeria Journal of Animal production. D o i : 10.4314/njap.V30i2.3293 VL-30.

Lesson, S. 1990. Energy intake for leghorns. Feed management. 41 (1): 27-31.

Lesson, S. and Summers, J. D. 1989. Response of leghorn pullets to protein and energy in the diet when reared in regular or hot- cyclic environment. Poult. Sci. 68: 546557.

Olomu, J. M. 1995. Monogastric Animal Nutrition Prrinciples and Practice. Jachem Pub. Benin Nigeria.

Oluyemi, J. A. and Roberts, F. A. 2000. Poultry production in warm wet Climate $\left(2^{\text {nd }}\right.$ Ed.), MaCmillian Press Ltd, London.

Onu, P. N. and Okongwu, S. N. 2006. Production characteristics and nutrient utilization of broilers fedraw and processed pigeon pea (Cajanus cajan) seed meal. International Journal of Poultry Science, 5(7): 693-697.
Sundu, B. 2009. Gastro-intestinal response and passage time of pelleted diets in digestive tract of broilers. International Journal of Poultry Science, 8 (10): 976-979.

Tangtaweewipat, S. and Elliott, R. 1989a. Nutritional value of pigeonpea (Cajanus cajan) meal In poultry diets. Animal Feed Science and Technology. 25: 123-135.

Tangtaweewipat, S. and Elliot, R. 1989b. Utilization of pigeon pea (cajanus cajan) as a poultry feed III. Evaluation of pigeon pea as a protein energy source in layer ration. Journal of Agriculture. 5 (I):37-45.

Tangtaweewipat S. and Elliot, R. 1988. Utilization of pigeon pea (cajanus cajan) as a poultry feed. II. Evaluation of pigeon pea as protein/energy source in broiler diets. Pages 1- 1 I in proceedings of the 26th Annual Agricultural Conference. Animal Veterinary and Fishery Division, 3-5 Feb. 1988, Bangkok, Thailand: Kasetsart University.

Udedibie, A. B. I. and Igwe, F. O. 1989. Dry matter yield and chemical composition of pigeon pea (Cajanus cajan) leaf meal and the nutritive value of pigeon pea leaf meal and grain meal for laying hens. Animal Feed Science and Technology 24: 111-119.

Received: $12^{\text {th }}$ July, 2019 Accepted: $17^{\text {th }}$ December, 2019 